\title{
Mean Absolute Percentage Error untuk Evaluasi Hasil Prediksi Komoditas Laut
}

\author{
Ida Nabillah ${ }^{1}$, Indra Ranggadara ${ }^{2}$ \\ Fakultas Ilmu Komputer, Universitas Mercu Buana \\ Jl. Meruya Selatan No. 01 Kembangan, Jakarta Barat 11650

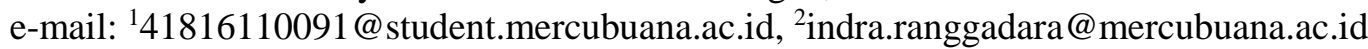

Diterima: 03 Agustus 2020; Direvisi: 16 Oktober 2020; Disetujui: 02 Nopember 2020

\begin{abstract}
Abstrak
Volume ekspor komoditas gurita mengalami kenaikan dan stok di suatu daerah akan tidak merata dan berlebih, serta bahwa permintaan gurita di beberapa negara tujuan di Asia, Eropa dan Amerika telah meningkat secara signifikan. Penelitian ini bertujuan untuk untuk memperkirakan pasokan gurita berdasarkan data historis dari tahun 2014 sampai 2018. Setelah dilakukan prediksi selanjutnya maka diperlukan untuk mengevaluasi model prediksi yang digunakan. Metode penelitian yang digunakan untuk memprediksi hasil komoditas yaitu dengan regresi linier, yang bertujuan untuk mengetahui nilai yang dipengaruh antara satu atau lebih dari satu variabel terhadap satu variabel. Selanjutnya evaluasi model yang digunakan menggunakan Mean Absolute Percentage Error (MAPE). MAPE memberikan suatu patokan seberapa besar kesalahan prediksi dibandingkan dengan nilai realisasi dari perhitungan yang dilakukan tersebut. Selanjutnya hasil produksi dapat diprediksi $70 \%$ dan hasil MAPE sebesar $30 \%$ maka dapat dikatakan bahwa hasil regresi linier memiliki kemampuan model peramalan yang layak.
\end{abstract}

Kata kunci: algoritma, evaluasi, mape, prediksi, regresi linear

\begin{abstract}
The volume of octopus commodity exports has increased, and stocks in an area will be uneven and excessive, and that the demand for octopus in several destination countries in Asia, Europe and America has increased significantly. This study aims to estimate the octopus supply based on historical data from 2014 to 2018. After further predictions, it is necessary to evaluate the prediction model used. The research method used to predict commodity outcomes is linear regression, aiming to determine the effect of one or several variables on one variable. Furthermore, the evaluation model used uses the Mean Absolute Percentage Error (MAPE). MAPE gives a clue how much forecast error compared to the actual value of the series. Furthermore, the production results can predict $70 \%$ and MAPE results by $30 \%$, it can be said that the results of linear regression can forecast feasible models.
\end{abstract}

Keywords: algorithm, evaluation, mape, prediction, linear regression

\section{PENDAHULUAN}

Salah satu produk yang selalu diminati pasar internasional dari hasil laut yang ada Indonesia adalah gurita. Sejak 2017, tren arus ekspor komoditas gurita telah menunjukkan bahwa permintaan gurita di beberapa negara tujuan di Asia, Eropa dan Amerika telah meningkat 
secara signifikan. Menurut statistik perikanan [1] dalam tabel di bawah ini, volume ekspor komoditas gurita telah meningkat terlihat pada tabel 1.

Tabel 1. Nilai dan volume ekspor gurita

\begin{tabular}{ccc}
\hline Tahun & Nilai (USD) & Volume (Ribu Ton) \\
\hline 2014 & 72.25 & 38.50 \\
2015 & 82.69 & 44.28 \\
2016 & 159.30 & 63.83 \\
2017 & 160.93 & 50.53 \\
2018 & 228.72 & 65.49 \\
\hline
\end{tabular}

Tabel 1 menjelaskan data pada tahun 2014 sampai dengan tahun 2018 persediaan gurita mengalami kenaikan, kenaikan terjadi pada tahun 2014 sampai 2016 sekitar sebesar 13\% dan juga mengalami penurunan pada tahun 2016 ke tahun 2017 sebesar 21\%, dan meningkat kembali pada tahun 2018 sebesar 23\%. Berdasarkan data dari tabel 1 dapat dikatakan bahwa hasil perikanan di Indonesia terdapat fluktuasi dalam kurun waktu lima tahun, sehingga diperlukan suatu metode supaya hasil yang didapatkan selalu dalam performa perningkatan yang baik untuk kebutuhan ekspor. Penelitian ini bertujuan untuk untuk memperkirakan pasokan gurita berdasarkan data historis dari tahun 2014 sampai 2018. Setelah dilakukan prediksi dengan menggunakan regresi linier karena dapat digunakan untuk metode peramalan [2] selanjutnya maka diperlukan untuk mengevaluasi model prediksi yang digunakan dengan menggunakan metode Mean Absolute Percentage Error (MAPE), untuk mencari angka Mean Absolute Percentage Error (MAPE) perlu dilakukan perhitungan dengan menemukan kesalahan absolute setiap periode yang data yang digunakan, kemudian melakukan pembagian dengan nilai observasi pada periode tersebut dan selanjutnya mencari rata-rata persentase absolute ini [3]. Mean Absolute Percentage Error (MAPE) digunakan apabila ukuran variable pada peramalan yang dilakukan adalah faktor yang berpengaruh dalam melakukan evaluasi akurasi peramalan yang dilakukan. Mean Absolute Percentage Error (MAPE) menunjukan tingkat kesalahan absolute hasil dari peramalan yang dilakukan dengan nilai yang sebenernya dari hasil actual yang diperoleh [4].

\section{PENELITIAN TERKAIT}

Keterkaitan penelitian yang dilakukan dengan penelitian sebelumnya yang dilakukan yaitu pertama penelitian yang dilakukan dengan peramalan metode ini menghasilkan nilai MAPE kurang dari 20\% [5]. Selanjutnya penelitian yang kedua menghasilkan suatu model regresi linear yang dimanfaatkan untuk menemukan seberapa besar tingkat dari calon konsumen yang diterima terhadap salah satu jenis mobil pada umumnya sehingga perusahaan mobil dapat mengetahui keperluan konsumen perihal mobil [6]. Penelitian yang ketiga menghasilkan MAPE menunjukkan bahwa metode R-forecasting dan V-forecasting serta Holt-Winters menghasilkan perkiraan dengan hasil akurat, namun Holt-Winters dinilai lebih mendekati akurat dibandingkan R-forecasting dan V-forecasting [7].

Kontribusi yang penulis berikan pada penelitian ini adalah untuk memberikan hasil evaluasi model untuk memprediksi hasil pasokan pada komoditas laut khususnya gurita dengan menggunakan metode regresi linear dan metode MAPE untuk melihat tingkat akurasi yang dihasilkan. Sehingga budidaya perikanan khususnya gurita dapat dikembangkan dengan optimal dengan hasil peramalan yang dilakukan. Potensi budidaya yang ada di suatu wilayah juga dapat diketahui dengan baik jika peramalan dilakukan dengan baik. Selanjutnya potensi budidaya yang telah didapat pada suatu wilayah dapat dikembangkan sesuai dengan lingkungan yang mendukungnya [8]. 


\section{METODE PENELITIAN}

\subsection{Algoritma Regresi Linear}

Regresi linear merupakan suatu metode atau alat dalam statistic yang dapat dimanfaatkan untuk menemukan seberapa besar satu atau lebih dari satu variable akan dipengaruhi oleh sebuah variabel. Kegunaan dari regresi linear salah satunya yaitu sebagai alat analisis yang lebih akurat, dengan ini kesulitan untuk menentukan tingkat perubahan suatu variabel terhadap variabel lain dapat ditemukan dengan mudah. Dengan demikian, analisis regresi dalam suatu prediksi angka variabel terikat pada angka variabel bebas akan lebih akurat [2]. Regresi linear adalah suatu bentuk relasi antara variabel bebas yang disimbolkan dengan huruf $\mathrm{x}$ dan variabel tergantung yang disimbolkan dengan huruf y sebagai faktor yang berpangkat satu. Berikut bentuk regresi linear yang dipakai dalam penelitian ini [9]:

$\mathrm{Y}=\mathrm{a}+\mathrm{bX}$,

\subsection{Mean Absolute Percentage Error (Mape)}

Mean Absolute Percentage Error (MAPE) adalah nilai rata - rata perbedaan absolut yang ada diantara nilai dari prediksi dan nilai realisasi yang disebutkan sebagai hasil persenan dari nilai realisasi. Penggunaan Mean Absolute Percentage Error (MAPE) pada evaluasi dari hasil peramalan dapat melihat tingkat akurasi terhadap angka peramalan dan angka realisasi. Nilai Mean Absolute Percentage Error (MAPE) dapat dihitung dengan menggunakan persamaan (2) berikut [10]:

$M A P E=\Sigma|x t-y t| x t n t=1 n \times 100 \%$

Adapun langkah yang dilakukan dalam penelitian ini untuk mengevaluasi model prediksi yang digunakan yaitu :

1. Menentukan data set yang akan digunakan pada penelitian ini, sesuai dengan data yang sudah didapatkan pada dari permasalahan yang ada.

2. Melakukan perhitungan dengan metode regresi linear sesuai persamaan (1), yaitu :

$\mathrm{Y}=\mathrm{a}+\mathrm{bX}$,

Dimana:

$\mathrm{Y}=$ Variabel Response atau Variabel Akibat (Dependent)

$\mathrm{X}=$ Variabel Predictor atau Variabel Faktor Penyebab (Independent)

$\mathrm{a}=$ konstanta

$\mathrm{b}=$ koefisien regresi (kemiringan); besaran Response yang ditimbulkan oleh Predictor.

3. Melakukan akurasi dengan perhitungan metode Mean Absolute Percentage Error

(MAPE), dengan persamaan (3) berikut :

$M A P E=\Sigma|x t-y t| x t n t=1 n \times 100 \%$

Dimana :

$\mathrm{xt}=$ nilai actual

$\mathrm{yt}=$ nilai prediksi

$\mathrm{n}=$ jumlah data

\section{HASIL DAN PEMBAHASAN}

Seiring dengan berkembangnya kemajuan teknologi sekarang ini yang sangat bermanfaat sekali bagi kita dalam mencari suatu informasi yang begitu cepat, tepat dan akurat [11]. Untuk itu data yang digunakan adalah data yang akurat sehingga hasil untuk membuat prediksi dengan menggunakan regresi linear dalam penelitian ini terdapat pada seperti tabel berikut di bawah ini dengan menggunakan data set hasil produksi gurita selama lima tahun sebelumnya. 


\begin{tabular}{|l|r|r|r|r|r|r|r|r|r|r|r|r|}
\hline & Januari & Februari & \multicolumn{1}{c|}{ Maret } & \multicolumn{1}{c|}{ April } & \multicolumn{1}{c|}{ Mei } & \multicolumn{1}{c|}{ Juni } & \multicolumn{1}{c|}{ Juli } & Agustus & September & Oktober & Nopember & Desember \\
\hline $\mathbf{2 0 1 4}$ & 71435 & 80468 & 79923 & 109066 & 111994 & 106404 & 100072 & 111993 & 106821 & 85854 & 112736 & 94946 \\
\hline 2015 & 96665 & 111882 & 97787 & 15630 & 16370 & 14907 & 17101 & 19793 & 20009 & 13746 & 14282 & 13737 \\
\hline 2016 & 34080 & 33196 & 37887 & 17082 & 15021 & 17290 & 10753 & 11115 & 10976 & 9940 & 9048 & 8407 \\
\hline 2017 & 34809.15 & 35255.80 & 38388.97 & 34328.09 & 38176.64 & 31567.92 & 36237.52 & 39254.84 & 31982.32 & 45721.84 & 40523.7 & 26812.02 \\
\hline 2018 & 32724.82 & 32322.22 & 42791.95 & 42419.87 & 28264.49 & 23718.04 & 37195.2 & 36332.93 & 39667.34 & 49488.48 & 43548.03 & 28617.55 \\
\hline
\end{tabular}

Gambar 1. Data set tahun 2014-2018

Kemudian dari data set di atas dihitung untuk prediksi satu tahun ke depannya menggunakan persamaan regresi linear dan menghasilkan data yaitu pada bulan Januari prediksi yang dibuat adalah 51204, bulan Februari prediksi yang dibuat adalah 52104, bulan Maret prediksi yang dibuat adalah 53004, bulan April prediksi yang dibuat adalah 53904, bulan Mei prediksi yang dibuat adalah 54904, bulan Juni prediksi yang dibuat adalah 55804, bulan Juli prediksi yang dibuat adalah 56704, bulan Agustus prediksi yang dibuat adalah 57604, bulan September prediksi yang dibuat adalah 58604, bulan Oktober prediksi yang dibuat adalah 59504, bulan Nopember prediksi yang dibuat adalah 60404, bulan Desember prediksi yang dibuat 61404. Hasil visualisasi dari regresi linear dibuat dengan menggunakan tools yaitu MATLAB versi R2013a, terlihat dalam gambar 1.
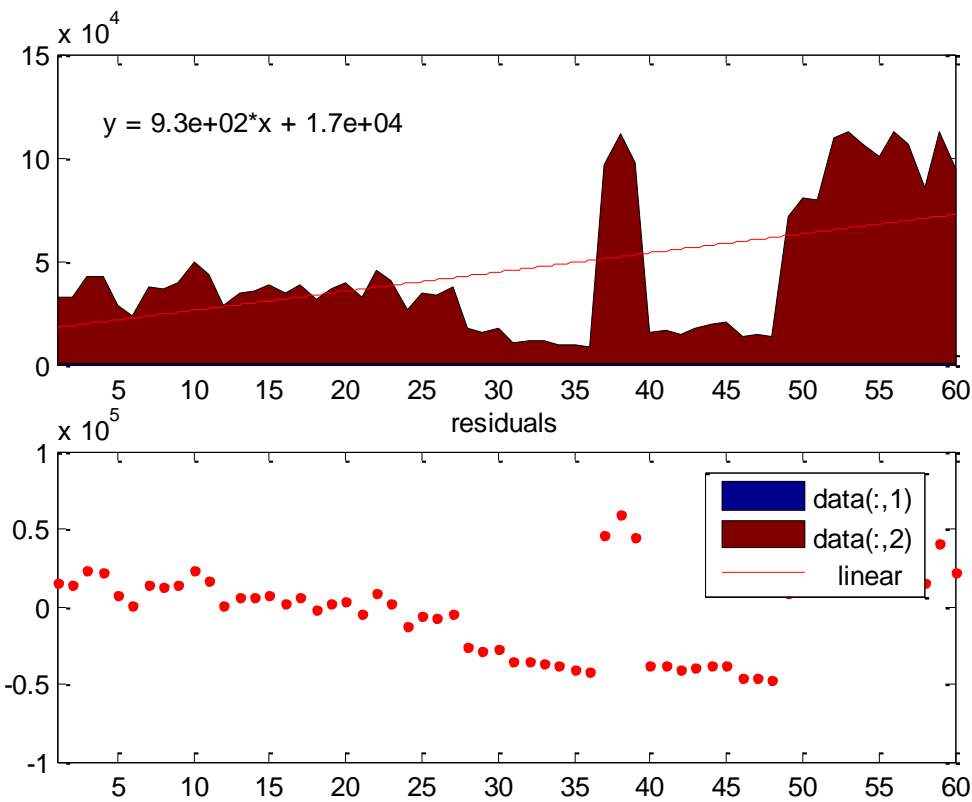

Gambar 1. Visualisasi regresi linear dalam prediksi komoditas gurita

Gambar 1 menjelaskan bahwa dari data set yang telah dimasukan ke dalam aplikasi matlab terlihat pada area yang berwarna merah adalah data yang telah dimasukan dari data ke 1 sampai ke 60 yang mengalami kenaikan dan penurunan sesuai dengan data yang diperoleh dari sumber data produksi komoditas laut khususnya gurita dari tahun 2014 sampai dengan 2018. Kemudian hasil prediksi menggunakan persamaan regresi linear terlihat ditunjukan dengan adanya garis lurus yang mengalami kenaikan mulai dari data pertama sampai dengan data ke 60 pada periode tahun 2014 sampai dengan 2018 dengan hasil akurasi sebesar 70\%. Selanjutnya adalah menghitung tingkat akurasi dengan metode Mean Absolute Percentage Error (MAPE), akurasi didapatkan dengan cara 100\% dikurangi dengan nilai MAPE. 
Tabel 2. Hasil mean absolute percentage error (MAPE)

\begin{tabular}{lrrr}
\hline \multicolumn{1}{c}{ Bulan } & Prediksi & \multicolumn{1}{c}{ Hasil Aktual } & \multicolumn{1}{c}{ MAPE } \\
\hline Januari (31) & 51204 & 96665 & -0.887840794 \\
Februari (28) & 52104 & 111882 & -1.147282358 \\
Maret (31) & 53004 & 97787 & -0.844898498 \\
April (30) & 53904 & 15630 & 0.710040071 \\
Mei (31) & 54904 & 16370 & 0.701843217 \\
Juni (30) & 55804 & 14907 & 0.7328686612 \\
Juli (31) & 56704 & 17101 & 0.698416337 \\
Agustus (31) & 57604 & 19793 & 0.656395389 \\
September (30) & 58604 & 20009 & 0.658572794 \\
Oktober (31) & 59504 & 13746 & 0.76899032 \\
Nopember (30) & 60404 & 14282 & 0.763558705 \\
Desember (31) & 61404 & 13737 & 0.776284933 \\
& & Jumlah & 3.586948727 \\
& & MAPE & 0.298912394 \\
& & MAPE (Dalam \%) & $30 \%$ \\
\hline
\end{tabular}

Tabel 2 menjelaskan bahwa hasil yang diperoleh dengan menggunakan MAPE pada penelitian ini sebesar 30\%. Dari perhitungan MAPE di atas dapat diartikan bahwa hasil pengurangan antara nilai aktual dan prediksi yang telah di absolute-kan, kemudian di bagi dengan nilai aktual per periode masing-masing, kemudian dilakukan penjumlahan terhadap hasil-hasil tersebut. Semakin rendah nilai MAPE, kemampuan dari model peramalan yang digunakan dapat dikatakan baik, dan untuk MAPE terdapat range nilai yang dapat dijadikan bahan pengukuran mengenai kemampuan dari suatu model peramalan, range nilai tersebut dapat dilihat pada tabel 3 [4].

Tabel 3. Range nilai MAPE

\begin{tabular}{ll}
\hline \multicolumn{1}{c}{ Range MAPE } & \multicolumn{1}{c}{ Keterangan } \\
\hline$<10 \%$ & Kompetensi Model Peramalan Sangat Baik \\
$10-20 \%$ & Kompetensi Model Peramalan Baik \\
$20-50 \%$ & Kompetensi Model Peramalan Layak \\
$>50 \%$ & Kompetensi Model Peramalan Buruk \\
\hline
\end{tabular}

Hasil yang diperoleh dari metode MAPE yaitu sebesar 30\%, untuk perhitungan evaluasi yaitu dihitung dengan menggunakan persamaan (3) [12], dan dikarenakan hasil tersebut maka range MAPE berkisar di 20-50\% maka dapat dikatakan bahwa hasil MAPE memiliki kemampuan model peramalan yang layak, sehingga metode yang digunakan dapat menjadi acuan untuk mengetahui prediksi beberapa periode waktu ke depan pada komoditas laut khususnya gurita.

\section{KESIMPULAN DAN SARAN}

Hasil dari prediksi menggunakan persamaan regresi linear untuk kebutuhan periode waktu satu tahun ke depan yaitu pada bulan Januari prediksi dengan akurasi sebesar $70 \%$, serta hasil dari evaluasi yang dilakukan dengan memanfaatkan metode Mean Absolute Percentage Error (MAPE) untuk mengetahui seberapa besar kemampuan model yang digunakan untuk melihat diferensiasi nilai aktual dan prediksi. Maka jika dilihat dari hasil 
prediksi yang didapatkan dari model regresi linier nilai MAPE berkisar di 20-50\% dan dapat dikatakan bahwa hasil MAPE memiliki kemampuan model peramalan yang layak. Dalam penelitian ini memiliki keterbatasan dalam jumlah datayang digunakan maka untuk meningkatkan hasil evaluasi Mean Absolute Percentage Error (MAPE) diperlukan adanya penambahan jumlah hitorikal data sebelumnya untuk mendapatkan hasil prediksi yang sesuai.

\section{DAFTAR PUSTAKA}

[1] BPS (Badan Pusat Statistik), STATISTIK Statistics of Fishing Port. 2017.

[2] P. Katemba and R. K. Djoh, "Prediksi Tingkat Produksi Kopi Menggunakan Regresi Linear," J. Ilm. FLASH, vol. 3, no. 1, pp. 42-51, 2017, [Online]. Available: http://jurnal.pnk.ac.id/index.php/flash/article/view/136.

[3] P. Jana, "Aplikasi Triple Exponential Smoothing Untuk Forecasting Jumlah Penduduk Miskin,” J. Deriv., vol. 3, no. 2, pp. 76-81, 2016.

[4] M. A. Maricar, "Analisa Perbandingan Nilai Akurasi Moving Average dan Exponential Smoothing untuk Sistem Peramalan Pendapatan pada Perusahaan XYZ," J. Sist. dan Inform., vol. 13, no. 2, pp. 36-45, 2019.

[5] J. I. Matematika, "MATH unesa," vol. 6, no. 2, pp. 70-74, 2018.

[6] N. Intan, P. Hati, and S. Nugroho, "Analisis Tingkat Penerimaan Calon Konsumen Terhadap Jenis Mobil Dengan Menggunakan Metode Regresi Linier," J. Tek. Elektro, vol. 8, no. 2, pp. 50-55, 2016.

[7] Y. A. Jatmiko, R. L. Rahayu, and G. Darmawan, "Perbandingan Keakuratan Hasil Peramalan Produksi Bawang Merah Metode Holt-Winters Dengan Singular Spectrum Analysis (Ssa)," J. Mat. "MANTIK," vol. 3, no. 1, p. 13, 2017, doi: 10.15642/mantik.2017.3.1.13-24.

[8] B. C. G. S. Worang, H. J. Sinjal, and R. D. Monijung, "Strategi pengembangan budidaya perikanan air tawar di Kecamatan Dimembe Kabupaten Minahasa Utara Provinsi Sulawesi Utara," e-Journal Budid. Perair., vol. 6, no. 2, pp. 68-76, 2018, doi: 10.35800/bdp.6.2.2018.20635.

[9] M. Syafruddin, "Metode Regresi Linier Untuk Prediksi Kebutuhan Energi Listrik Jangka Panjang (Studi Kasus Provinsi Lampung)," J. Inform., vol. 2, no. 1, pp. 1-9, 2014, doi: http://dx.doi.org/10.1097/DBP.0b013e318165c100.

[10] B. Putro, M. T. Furqon, and S. H. Wijoyo, "Prediksi Jumlah Kebutuhan Pemakaian Air Menggunakan Metode Exponential Smoothing ( Studi Kasus : PDAM Kota Malang )," J. Pengemb. Teknol. Inf. dan Ilmu Komput. Univ. Brawijaya, vol. 2, no. 11, pp. 4679-4686, 2018.

[11] R. Tulhawa and R. Fajriah, "Analisa Dan Perancangan Sistem Informasi Penjualan Dan Pengelolaan Barang Berbasis Web (Studi Kasus: Butik Anne Riani)," vol. 2, no. 3, pp. 122-129, 2019.

[12] A. P. Widodo, E. A. Sarwoko, and Z. Firdaus, "Akurasi Model Prediksi Metode Backpropagation Menggunakan Kombinasi Hidden Neuron Dengan Alpha," Matematika, vol. 20, no. 2, pp. 79-84, 2017. 